DOI: https://doi.org/10.17355/rkkpt.v27i3.277

KOVÁCS NÓRA*

\title{
Transznacionális migráns vállalkozók gyermekgondozási stratégiái a gondozók tükrében: kínai gyerekek magyar otthonokban
}

\section{Bevezetés}

$\mathrm{T}$ anulmányom a szociokulturális antropológia szemszögéből mutatja be és tárgyalja a Magyarországon tevékenykedő kínai migráns vállalkozók között megfigyelt gyermekgondozási gyakorlatokat, amelyek szorosan összekapcsolódnak saját maguk és családjuk transznacionális migrációjának folyamataival. E gyerekgondozási megoldások már a magyarországi kínai diaszpóra kialakulásának időszakában, az 1990-es években is megfigyelhetőek voltak, és több szempontból, kiváltképp a kiszervezett gondoskodás helyszínében és időtartamában, különböztek attól, ahogyan ezt a magyarországi középosztálybeliek tették (a még nem óvodás korú gyermek elhelyezése állami, esetleg magánbölcsődében vagy családi napköziben; illetve óradíjban fizetett bébiszitter által nyújtott felügyelet a gyermek otthonában).

Azt nem tudjuk pontosan, hogy a magyarországi szülöknek mekkora hányada fizet egyének által informálisan nyújtott gyerekfelvigyázási szolgáltatásért, hiszen ez a tevékenység a gazdaság fekete zónájában zajlik. Az állami bölcsődék és óvodák, valamint a családi napközik rendszere Magyarországon országos és mindenki számára ingyenesen hozzáférhető hálózatot alkot. Emellett Európában Magyarország nyújtja az egyik leghosszabb ideig igénybe vehető szülés után szabadságot. Egy 2012-ben végzett felmérés szerint a

* A szerző a TK Kisebbségkutató Intézet tudományos munkatársa. E-mail: kovacs.nora@tk.mta.hu

REGIO 27. évf. (2019) 3. szám 149-182. 
munkába visszatérő nők nem több mint 3\%-a vett igénybe fizetett privát gyerekfelvigyázást. ${ }^{1}$

A Magyarországra érkezett kínai vállalkozók ugyanakkor egyedi posztmigrációs gyerekgondozási gyakorlatot alakítottak ki, amely során bevándorlók magyar személyeket alkalmaznak gyermekgondozásra, és amelyben így a „nemzetközi reprodukciós munkamegosztás" ${ }^{2}$ fordított esete valósul meg. A magyarországi kínai népességre irányuló empirikus kutatások alátámasztani tủnnek a jelen vizsgálat eredményeit, amelyek szerint ez a gyermekgondozási stratégia dominánsnak tekinthető a Magyarországon dolgozó kínai migráns vállalkozók körében.

Kutatásom a transznacionális családi mobilitás egy adott szakaszát megtapasztaló kínai migráns gyerekekre összpontosított. E mobilitás során ezekről a gyerekekről rövidebb-hosszabb időszakokon keresztül a magyar befogadó társadalom felnőtt tagjai gondoskodnak, ök nevelik öket, miközben szüleik is Magyarországon élnek és dolgoznak. A kutatás tágabban Közép-Európába érkezett ázsiai bevándorlóknak a transznacionális migrációt követően kialakított ${ }^{3}$ gyerekgondozási megoldásait is vizsgálta; célja volt továbbá, hogy feltárja, miként müködnek a Magyarország és Kína között mozgó transznacionális családok. Fókuszában a transznacionális családban töltött mobil gyermekkor ${ }^{4}$ állt, és megkísérelte összekötni a gyerekgondozással kapcsolatos speciális jelenségegyüttest a bevándorlók integrációjával. ${ }^{5}$

Bár a vizsgálat során a figyelem a kínai szülőkre és fiatalokra is irányult, jelen dolgozat ezt a gyermekgondozási gyakorlatot terjedelmi szempontból elsősorban a magyar gyermekgondozók nézőpontjából mutatja be. Ugyanakkor a kínai szülők e tanulmányban

1 Makay Zsuzsanna: Családtámogatás, gyermeknevelés, munkavállalás. In: Monostori Judit - Öri Péter- Spéder Zsolt (szerk.): Demográfiai portré. Budapest: KSH, 2015. 57-75.

2 Parreñas, Rhacel Salazar: Transnational Mothering: A Source of Gender Conflicts in the Family. University of North Carolina Law Review, 2010. 88(5). 1825-1856.

${ }^{3}$ L. Souralová, Adéla: New perspectives of mutual dependency in care-giving. Farnham: Ashgate, 2015.

${ }^{4}$ Fresnoza-Flot, Asuncion - Nagasaka, Itaru (eds.): Mobile childhoods in Filipino transnational families. New York: Palgrave Macmillan, 2015.

${ }^{5}$ Souralová, 2015.

REGIO 27. évf. (2019) 3. szám 149-182. 
tárgyalt gondoskodási formáinak értelmezéséhez támpontot nyújthat néhány tágabb érvényü, általánosabb szakirodalmi megállapítás megtétele a kínai szülők gyerekekkel kapcsolatos elképzeléseinek és elvárásainak rendszeréről, valamint az ezekkel összefüggő, szociokulturálisan kondicionált szülői stratégiákról.

A kínai és az indiai szülők gyerekneveléséről értekezve Nirmala Rao és szerzőtársai kiemelik, hogy a családdal kapcsolatos elképzelések alakulásában jelentős szereppel bíró konfucianizmus elgondolása szerint a gyermek fejlődésére a legnagyobb hatást a környezete fejti ki. A gyerek felneveléshez a szülőknek tanácsos a lehető legjobb környezetet biztosítaniuk. ${ }^{6}$ A kínai szülők úgy vélik továbbá, hogy a nagyon fiatal gyermekek még nem képesek a „megértésre”, ezért rendkívül elnézőek velük, ${ }^{7}$ azonban amint elérik a „megértés korát”, szigorú szabályoknak vetik alá őket. ${ }^{8}$ Rao és kutatótársai továbbá azt is hangsúlyozzák, hogy a hagyományos kínai társadalom hierarchikusan szervezett és patriarchális, valamint azt is, hogy a kínai családban a családtagok közti viszonyok, a szülök iránti engedelmesség, a családi felelösségvállalás, valamint a családtagok egymástól való függése fontos mozzanatok.

A kínai gyerekek nemzetközi örökbefogadásáról szóló könyvében Leslie K. Wang amerikai szociológus szembeállítja a „nyugati” és a kínai szülők gyerekekkel kapcsolatos nézeteit és elvárásait. Wang azt állapítja meg, hogy a ,nyugati” szülök számára gyermekeik a hozzájuk füződő érzelmi kapcsolat miatt rendkívül értékesek, míg a kínai gyerekek értékét szüleik számára jövőbeli gazdasági produktivitásuk határozza meg. Történeti fejezetében Wang arra is rámutat, hogy a kínai szülöi stratégiákat nagyban befolyásolták a gyermek társadalmi értékét meghatározó kormányzati politikák, és az a törekvés, hogy a gyerekek minőségének (suzhi) emelésén keresztül egy „magas minőségü”, versenyképes, modern népességet hozzanak létre Kínában.

\footnotetext{
${ }^{6}$ Rao, Nirmala - McHale, James - Pearson, Emma: Links between socialization goals and child-rearing practices in Chinese and Indian mothers. Infant and Child Development, 2003. 12(5). 475-492. 476.

7 Ez egybecseng néhány, a vizsgálatban résztvevő kínai szülő azon megállapításával, hogy gyerekeik úgysem emlékeznek semmire, ami négyéves koruk elött történik velük.

${ }^{8}$ Rao et al., 2003. 477.
}

REGIO 27. évf. (2019) 3. szám 149-182. 
A tanulmányban tárgyalt kiszervezett gondoskodási forma jelenségét jól példázza Dávid ${ }^{9}$ története, mivel számos kínai kortársának élete hasonló forgatókönyvet követett Magyarországon, mint az övé. Dávid 2004-ben született Budapesten egy kínai vállalkozó család gyermekeként. Élete első két évét Budapesten töltötte. Néhány héttel a születése után szülei megfizettek egy magyar nőt, aki saját otthonában gondoskodott az újszülöttről. Amikor kétéves lett, szülei úgy döntöttek, elküldik Kínába. Ott elöször apai nagyszüleinek otthonában élt, majd hosszabb időszakokat töltött apja lánytestvéreinek otthonaiban. Kínában kezdte meg az általános iskolát, és teljesen elfelejtette első nyelvét, a magyart. Amikor betöltötte a tízet, szülei úgy ítélték meg, hogy itt az ideje, hogy visszatérjen Magyarországra, és beköltöztették a terepmunkám idején hatvanas éveiben járó Gizi nénihez. Amikor megismertem öket 2016ban, Dávid több mint egy éve lakott gondozója, Gizi néni házában egy csendes pesti zöldövezeti utcában.

Mindez idő alatt Dávid szülei Budapesten éltek és dolgoztak a nagycsaládi transznacionális kereskedelmi vállalkozásukban. Munkájuk miatt évente többször utaztak Kínába és más országokba is. Dávid édesanyja, édesanyjának három testvére, valamint az ő házastársaik is ugyanabban a családi vállalkozásban dolgoztak, amelyet az 1990-es évek elején Délkelet-Kínából egy szál börönddel érkezett édesanyjuk hozott létre. Ez a cég nagyon sikeres lett, és az egész családi csoportot rendkívül jómódúvá tette.

Visszatérte után 2015-ben Dávid a körzeti általános iskolában folytatta a tanulmányait. Három hónappal a tanév vége előtt az általános iskola 3. osztályába íratták be, bár kínai tanulmányai és életkora szerint a negyedikbe kellett volna becsatlakoznia. Bár idősebb volt az osztálytársainál, szülei ragaszkodtak ehhez a megoldáshoz, mondván, az alsó tagozat utolsó két évében meg tud tanulni magyarul, és a felső tagozatban majd sikeresebb lesz. Dávid anyukája, a negyven felé közelítő Mimi a középiskola befejezése után érkezett Kínából Magyarországra. Anyjával ellentétben kellőképpen megtanult magyarul ahhoz, hogy a fiával kapcsolatos alapvető kérdéseket megbeszélje. Dávid ügyében Mimi tartotta a kapcsolatot Gizi nénivel. Hetente, kéthetente látogatta meg Dávidot; ilyenkor 1015 percig maradt, és Dávid mindennapjaival kapcsolatos gyakorlati

\footnotetext{
${ }^{9}$ A kutatásban részvevő személyek nevét megváltoztattam.
}

REGIO 27. évf. (2019) 3. szám 149-182. 
kérdéseket tárgyalt meg Gizi nénivel. Hétvégénként egyszer étterembe vitte ebédelni vagy vacsorázni Dávidot, aki az éjszakákat hétvégénként is Gizi néni házában töltötte. Dávidot évente kétszer is elvitték a szülei külföldre nyaralni; a Budapestre érkezése utáni első nyáron az USA-ba és Mexikóba, a rákövetkező nyáron Görögországba és Spanyolországba. A nyári szünetből három-négy hetet az apai nagyszüleinél töltött Kínában. Dávid édesapja, aki ugyancsak első generációs kínai volt Magyarországon, csak olyankor jelent meg Gizi néni házában, amikor felesége üzleti úton volt. Gizi néni úgy érzékelte, hogy a szülők látogatásaik során alapvetően azt akarták ellenőrizni, fiuk jó egészségnek örvend-e, illetve pénzt hoztak Dávid költségeinek fedezésére, különórákra, sportfoglalkozásokra, étkezésére, valamint esetileg játékokra is.

A Gizi néni házában tett látogatások során lehetőségem nyílt nyomon követni Dávid budapesti helyzetének alakulását. Gizi néni meglepetésére Dávid úgy döntött, hogy minden reggel 4 órakor kel fel, és negyed 5-kor elfogyasztja a Gizi néni által felszolgált reggelit. Reggel együtt sétáltak el a közeli általános iskolába, és délután együtt sétáltak haza. Minden délután magántanárok adtak neki különórákat Gizi néninél. Ezek között a szülők számára kiemelt fontossággal bírtak az angolórák. Dávid egyetlen házon kívüli elfoglaltsága a karateedzés volt, ahová Gizi néni kísérte el hetente két alkalommal. Ha Dávid megbetegedett, Gizi néni vitte el a körzeti gyerekorvoshoz, és az iskolával is ő tartotta a kapcsolatot, mint Dávid „,nagymamája”. A beszámolók arra engedtek következtetni, hogy Dávid nem érezte jól magát az iskolában, ahol gyakran került konfliktusba tanáraival. Nála fiatalabb osztálytársait hol levegönek nézte, hol sorozatos összetüzésbe került velük.

Dávid nem az első kínai gyerek volt, akiről az elvált Gizi életvitelszerüen gondoskodott azt követően, hogy hazatért Ausztriából, ahol férjével korábban egy éttermet üzemeltettek. Dávid érkezése előtt már lakott nála két kínai gyerek, és néhány hónappal első beszélgetésünk után elvállalta Dávid ötéves unokaöccsének ellátását is.

Gizi néni szokatlan gyerekként jellemezte Dávidot, olyasvalakiként, akit majd szétvet az elégedetlenség, és aki közben felsőbb rangúan viselkedik; aki sosem szólítja őt a nevén, és aki főleg

REGIO 27. évf. (2019) 3. szám 149-182. 
parancsokat osztogat. ${ }^{10}$ Gizi többször tett rá kísérletet, hogy moziba, állatkertbe, cirkuszba vigye Dávidot, ám sosem járt sikerrel. Dávid szívesebben ette meg otthon a számára vendéglőből rendelt ételt, minthogy kimozduljon; a cirkuszt és az állatkertet rossz szagú helyeknek tartotta, és nem mutatott érdeklődést a mozi iránt sem. A szülei nem tartottak vele online kapcsolatot, és azt sem engedték meg neki, hogy okostelefont vagy táblagépet használjon, mert nem akarták, hogy internetes játékokat játsszon; ugyanakkor szabadott tévét néznie, legóznia, és voltak elektronikus játékai is.

Dávid nem egyedüli gyerek volt. Két nővére közül az idősebbik 11 éves volt 2016-ban, a nagyszülőkkel élt, és a család elmondása szerint kimagasló eredményekkel éppen akkor fejezte be a középiskolát Kínában. A családnak az volt a kívánsága, hogy Kínában járjon egyetemre. Dávid másik nővére csak egy évvel volt idősebb nála, és ugyancsak a nagyszülőkkel élt Kínában, de 2015 nyarát Gizi néninél töltötte, így a két testvér néhány hétig egy fedél alatt lakott. Gizi néni mesélte, hogy a szülök a fiatalabb nővért is Magyarországra tervezték költöztetni, de egy másik, nálánál lényegesen fiatalabb magyar hölgyet választottak ki a számára gondozóként.

\section{Módszertan}

Ez a tanulmány a magyarországi kínai népesség és a magyar társadalom tagjai közt létrejött bensőséges kapcsolatokat vizsgáló „Kínai a családban” címü antropológiai kutatás adatai alapján készült el. ${ }^{11}$ A projekt egyfelől a vegyes házasságokra, másfelől a kínai

\footnotetext{
${ }^{10}$ A kutatás során nem sikerült feltárni, hogy Dávid Gizi által leírt állapotának kialakulásában vajon milyen szerepet játszott a jelen írásban tárgyalt kiszervezett gondoskodási forma. A megszokott otthoni környezettől és a vele együtt élő családtagoktól és barátoktól való elszakadás, a kínai és a magyarországi környezet nagyfokú különbözősége által kiváltott kulturális sokk, a magyar nyelvtudás hiányosságai és az ezzel összefüggő iskolai nehézségek, a magyarországi iskolarendszer rugalmatlansága és felkészületlensége a bevándorló gyerekek integrációjára együttesen komoly kihívást jelenthettek a 11 éves fiú számára.

${ }^{11}$ L. még Kovács, Nóra: Cultures unfolding: Experiences of Chinese-Hungarian mixed couples in

Hungary. Current Issues in Personality Psychology, 2015. 3(4). 254-264. Kovács, Nóra: Global migration and intermarriage in Chinese-Hungarian context. In: Ducu, Viorela - Telegdi-Csetri, Áron (eds.): Managing difference in Eastern-European
} 
szülök, a kínai gyerekek és a gyerekekröl gondoskodó magyar felnőttek közti viszonyokra, valamint arra irányult, e kapcsolatok milyen szerepet töltenek be a gyerekek életében, viselkedésében, önazonosságában és kötődéseiben.

Antropológiai terepmunka, résztvevő megfigyelések és interjúk adatai alapján igyekeztem feltárni a három érintett társadalmi csoport tapasztalatait, narratíváit és az e gondoskodási formához kapcsolódó társadalmi gyakorlatokat. Budapesten (is) dolgozó kínai szülőkkel és kínai fiatalokkal, és kínai gyerekekről gondoskodó, ugyancsak Budapesten élő magyar felnőttekkel készültek interjúk, a kutatás során szám szerint 48. Ez a tanulmány elsősorban a 14 magyar felnőttel folytatott beszélgetés alapján az ő szempontjukból mutatja be a kulturális találkozások eme bensőséges helyzeteit. A részben strukturált gondozói interjúk egyebek mellett azt igyekeztek feltárni, milyen egyéni élethelyzetek, tapasztalatok és kapcsolatok vezettek a kínai családokhoz füződő speciális munkakapcsolathoz; ténylegesen milyen időtávon keresztül és hogyan zajlott az egyes kínai gyerekekröl való gondoskodás; milyen képük alakult ki a kínai szülökröl és gyerekekröl; miként alakult a kapcsolat köztük és a gyerekek között; és melyek voltak e tevékenység kihívásai és következményei. Ez a 14 magyar személy összesen 38 kínai gyerekről gondoskodott hosszabb időszakokon keresztül a saját háztartásában.

\section{Kontextus, problémák}

A kiszervezett gondoskodás bentlakó formái (amelyekben a gyerek hónapokon vagy éveken keresztül a gondoskodó személy háztartásában él) a bevándorlók és a helybéliek közti találkozások nagyon intenzív és intim helyzeteit hozták létre, és megkülönböztetett figyelmet kaptak ebben a kutatásban. A terepmunka jelezte, hogy a kínai gyerekek magyar felnőttek általi felügyeletének különféle formái is léteznek. Amióta megkezdték ezt a tevékenységet, a kínai gyermekeket felügyelő magyar személyek olyan munkaportfóliót alakítottak ki, amelyben kombinálták a bentlakó gyerek felügyeletét további kínai gyerekek délutáni vagy hétvégi felügyeletével, illetve délutáni korrepetálással, ugyancsak a saját otthonukban. A kutatás

transnational families . Frankfurt: Peter Lang, 2016. 113-131. A K-112282 számú OTKA kutatás 2014 és 2017 között futott.

REGIO 27. évf. (2019) 3. szám 149-182. 
látóterébe került kínai gyerekek és fiatalok többsége kezdetben hosszabb időn keresztül a róla gondoskodó magyar felnőtt otthonában élt, amely később délutáni vagy hétvégi felügyeletté, esetleg a leckeírásban nyújtott eseti délutáni foglalkozássá vált.

A kiskamasz Dávid egyéni transznacionális mobilitásának története és magyar gondviselőjével kialakult kapcsolata nem egyedi a magyarországi kínai migráns gyerekek között. A magyarországi kínai migráns népességgel kapcsolatos szakirodalom megerősíteni látszik, hogy a gyerekekröl való gondoskodás e formája elterjedt gyakorlat a kínai migráns vállalkozók között Magyarországon. ${ }^{12}$ Szakirodalmi adatok jelzik ugyanakkor, hogy előfordult Kelet-Európa más országaiban is, például Szerbiában ${ }^{13}$, valamint Csehországban ${ }^{14}$, illetve azt is, hogy a Csehországban dolgozó vietnami kereskedők is hasonló gyerekgondozási formákat alakítottak ki cseh asszonyok közremüködésével. ${ }^{15}$

Kínában a gyerekekről való gondoskodás nagyon sokféle, szociokulturálisan eltérően kondicionált gyakorlatok együttesét alkotja egy olyan társadalom kontextusában, amelyben a családi kapcsolatok és általában az interperszonális viszonyok is gyors ütemben változnak ${ }^{16}$. E területen fontos változást hozott az egy

12 Lásd Nyíri Pál: Kínaiak és afgánok Magyarországon: két migráns csoport érvényesülési stratégiái. In: Feischmidt Margit - Nyíri Pál (szerk.): Nem kívánt gyerekek? Külföldi Gyerekek magyar iskolákban. Budapest: MTA NemzetiEtnikai Kisebbségkutató Intézet - Nemzetközi Migrációs és Menekültügyi Kutatóközpont, 2006. 39-74.; Paveszka Dóra - Nyíri Pál: Oktatási stratégiák és a migráns tanulók iskolai integrációja. In: Feischmidt Margit - Nyíri Pál (szerk.): Nem kívánt gyerekek? Külföldi gyerekek magyar iskolákban. Budapest: MTA Nemzeti-etnikai Kisebbségkutató Intézet - Nemzetközi Migrációs és Menekültügyi Kutatóközpont, 2006. 129-169.; Nyíri Pál: Kínai migránsok Magyarországon: Mai tudásunk és aktuális kérdéseink. In: Hárs Ágnes - Tóth Judit (szerk.): Változó migráció - változó környezet. Budapest: MTA PTI, 2010. 147-171.; Beck Fanni: De ha a tükörbe nézek, az arcom kínai. Másodgenerációs kínai fiatalok hibrid identitáskonstrukciói. Budapest: MAKAT Antroport, 2015.

13 Korac Sanderson, Maja: Chinese traders in Serbia: Gender opportunities, translocal family strategies and transnational mobility. Ars\&Humanities, special issue Many Faces of Migration, VII(2). 2013. 86-98.

${ }^{14}$ Zdenek Uherek szóbeli közlése alapján. Poznan, 2019. március 31.

${ }^{15}$ Souralová, 2015.

${ }^{16}$ L. Naftali, Orna: Empowering the child: Children's rights, citizenship and the state in contemporary China. The China Journal, 2009. 61, 79-103.; Evans, Harriet: The gender of communication: changing expectations of mothers and

REGIO 27. évf. (2019) 3. szám 149-182. 
gyermek politikájának eltörlése 2015-ben, akárcsak e döntés komplex társadalmi és demográfiai következményei is. Kínában a gyerekekről való gondoskodás normái, informális szabályai nemritkán vezetnek ahhoz a tényleges gyakorlathoz, hogy nagyszülők vagy más rokonok látják el ezt a feladatot. ${ }^{17}$

A saját gyermek gondozásának ilyen jellegű és időtávú kiszervezése nem családtagoknak azonban semmiképpen nem a dolgozó kínai szülők domináns stratégiája sem Kínában, sem a Nyugat-Európában, Észak-Amerikában vagy Afrikában élő kínaiak körében. Ez a megoldás nem jelent meg például az európai országok közül a legtöbb első generációs kínai bevándorlót befogadó Franciaországban sem.

A kiszervezett gyermekgondozás e formája a kínaiak körében nem egy közelmúltban kialakult folyamat eredménye Magyarországon, hiszen kutatók már jóval korábban is leírták. ${ }^{18}$ Interjúalanyaim között is szerepelt egy olyan házaspár, amely az 1990-es évek eleje óta folyamatosan gondoskodtak otthonukban egy-egy kínai kisgyerekröl. Úgy vélem, e gondoskodási megoldások megvalósulását segítették azok a kulturális normák, amelyek Kínában nagyobb teret engednek abban, ki gondozza a gyerekeket, ugyanakkor ezek nem jöttek volna létre egyfelől a kínai vállalkozók transznacionális tevékenysége és a vállalkozásaikban rejlő növekedési potenciál, valamint a női vállalkozók jelenléte, másfelől a rendszerváltás utáni Magyarország kulturális, társadalmi és gazdasági tényezői nélkül. A munkanélküli vagy meggyengült munkaerő piaci helyzetü, középkorú vagy annál

daughters in urban China. The China Quarterly, 204. Evans, Harriet Gender in Flux: Agency and Its Limits in Contemporary China (DECEMBER 2010), 9801000.; Stafford, Charles (ed.): Ordinary ethics in China, LSE Monographs on Social Anthropology 79. London: Bloomsbury, 2013.; Fong, Vanessa. L.: China's one-child policy and the empowerment of urban daughters. American Anthropologist, 2002. 104(4), 1098-1109.; Kwok-bun, Chan (ed.): International Handbook of Chinese Families. New York: Springer, 2013.; Yan, Yunxiang: The individualization of Chinese society. LSE Monographs on Social Anthropology 77. Oxford: Berg Publishers, 2009.

${ }^{17}$ L. Chen, F. - Liu, G. - Mair, C.: Intergenerational ties in context: Grandparents caring for grandchildren in China. Social Forces, 90(2). 571-594., 2011. DOI:10.1093/sf/sor012

${ }^{18}$ L. pl. Feischmidt Margit - Nyíri Pál (szerk.): Nem kívánt gyerekek? Külföldi Gyerekek magyar iskolákban. Budapest: MTA Nemzeti-Etnikai Kisebbségkutató Intézet - Nemzetközi Migrációs és Menekültügyi Kutatóközpont, 2006.

REGIO 27. évf. (2019) 3. szám 149-182. 
idősebb, felsőfokú képesítéssel rendelkező középosztálybeli női munkaerő megléte kedvezett e gondozási konstrukció létrejöttének, és a kínai családok szempontjából e tényezőket kedvezően egészítették ki e nök hagyományos nemi szerepeihez köthető gondoskodási gyakorlatok és attitüdök. Hangsúlyozni szeretném mindemellett, hogy a kutatás tapasztalatai alapján nem minden itt élő kínai gyermeke részesül ebben a gondoskodási formában, illetve hogy a kiszervezett gondoskodás írásomban tárgyalt formája is számottevő változatosságot mutat.

Dávid Kínában és Magyarországon zajló élete, Gizi nénivel való kapcsolata számos egymáshoz kapcsolódó kérdést vet fel; ezek közül több túlmutat a jelen dolgozat keretein. A kutatás egyik központi célja volt bemutatni, miként müködik ez a létező, ám mégis kevéssé ismert gyermekgondozási forma, amelyet kínai családok és magyar egyének hoztak létre, előbbiek transznacionális migrációjának részeként. Hogyan és miért jönnek létre ezek a kapcsolatok? Vajon kialakultake jellegzetes mintázatai? Milyen ismérvekkel írhatók le a résztvevő kínai és magyarországi személyek? Hogyan tárgyalják meg és rögzítik az együttműködés sarokpontjait? Vajon valószínüsíthető, hogy minden Magyarországon dolgozó kínai ezt a megoldást választja?

A terepmunka során a gondozókkal és a gyerekekkel való találkozások láthatóvá tették a köztük kialakult kötelékeket, és hogy e bensőségesség milyen szerepet tölt be e két csoport tagjainak életében. Felvetették ugyanakkor a kérdést, hogy vajon e bensőséges kötelékek milyen hatást fejtenek ki a Magyarországon dolgozó kínai vállalkozó családok transznacionális migrációs folyamataira? Vajon a kínai gyerekek és a magyar felnőttek közt kialakult kötelék a helyi társadalomba vezető integráció csatornájává válik? Ha igen, ez miként valósul meg? Miként hat a migráns gyerekek gyerekkorára, személyes integritására (egy újabb kulturálisan kondicionált fogalom), személyiségfejlődésére? E jelenségegyüttes etnográfiai bemutatása és értelmezése segíthet megérteni rövid és hosszú távú következményeit a helyi társadalom tagjai, valamint a migráns családok, különösképpen pedig a migráns gyerekek számára. Azt is feltárhatja, hogy a gyermekekről való gondoskodás ezen formái és az általuk megélt tapasztalatok hogyan illeszkednek a transznacionális gyerekkor folyamatába. Mi több, támpontot nyújthat abban, hogyan befolyásolja az itt élő kínaiak integrációját, valamint a második generáció identitását.

REGIO 27. évf. (2019) 3. szám 149-182. 
A kutatás segített abban, hogy tudatára ébredjek annak, hogy a ,jó gondoskodásról" és a ,jó gyerekkorról" való saját fogalmaim és elképzeléseim milyen mértékben szociokulturálisan kondicionáltak, és ezek miként befolyásolhatják a terepmunka során gyüjtött adatok értelmezését. Ennek jelentőségére egyébként egy amerikai szociológusnő, Leslie K. Wang is felhívta a figyelmet, amikor hangsúlyozta a különféle gyermekgondozási gyakorlatok mögött meghúzódó kulturális logikákat, illetve ezeknek a társadalmi osztályhoz tartozás általi meghatározottságát. Wang egy pekingi állami árvaházban önkéntes munkát végző észak-amerikai és európai üzletember-feleségek gyerekgondozási gyakorlatait elemezve hangsúlyozta e társadalmi gyakorlatok mögött meghúzódó különféle logikák rendszerét. ${ }^{19}$

\section{A kínai népesség és a kínai vállalkozások Magyarországon}

A magyarországi kínai népesség nagymértékben különbözik a nyugateurópai, észak-amerikai és ausztráliai kínai diaszpóráktól. Viszonylag új, gazdaságilag motivált migráció eredményeként jött létre az 1990es évektől kezdődően. Tagjai kevésbé integrálódtak a befogadó ország társadalmába, mint azok a kínai diaszpóra közösségek, amelyek több generáció óta élnek egy adott helyen. A magyarországi kínai diaszpóra létszáma az 1990-es évek közepén becsült 40 ezer föről a 2010-es évtized közepére megközelítőleg 15 ezer före esett vissza. ${ }^{20}$

Meg kell jegyezni azonban, hogy két jelentős változás következett be a magyarországi kínai lakosság összetételében a legutóbbi években. Egyrészt több nagyon vagyonos kínai érkezett Magyarországra letelepedési kötvény vásárlásával, másrészt megjelentek Budapesten olyan középosztálybeli kínai családok is, akiket számos gazdasági és politikai tényező mellett az európai életmód, kultúra, a városi életforma és az általa kínált lehetőségek vonzottak ide, s akik családjuk, gyermekeik jövőjét Magyarországon képzelik el. Úgy tünik, e két csoport tagjainak megélhetése a Kínában

\footnotetext{
${ }^{19}$ Wang, Leslie. K.: Outsourced Children. Orphanage Care and International Adoption in Globalizing China. Stanford University Press, 2016.

${ }^{20}$ Magyarországon tartózkodó külföldi állampolgárok földrészek, országok és nemek szerint (1995-). Utolsó letöltés: 2019. november 11. Elérhető online: https://www.ksh.hu/docs/hun/xstadat/xstadat_eves/i_wnvn001b.html?down=147
}

REGIO 27. évf. (2019) 3. szám 149-182. 
megszerzett vagyonhoz, és nem magyarországi munkavégzéshez kapcsolódik, magyarországi életvitelük pedig egyfajta európai kulturális polgári, „kulturbürger” értékrend megélését célozza Budapesten, egy kisebb léptékü, kevésbé szennyezett, NyugatEurópánál alacsonyabban árazott, mégis európai hagyományokkal rendelkező városban. ${ }^{21} \mathrm{E}$ népesség tömeges érkezése a tágabb kutatáshoz kapcsolódó terepmunka időszakára esett, amikor is jó anyagi helyzetü, látványosan jól öltözött, gyakran több generációs kínai családok kisgyerekeikkel-unokáikkal együttesen kezdtek el megjelenni Budapest városi tereiben. Magam a II. kerületben tapasztaltam meg ezt a jelenséget a Millenáris Park környékén, annak játszóterein, a szomszédos sétálóutcában, valamint a Budai Tánciskolában. Ezeken a helyeken a kínai gyerekek a kínai felnőttek személyes kíséretében jelentek meg, nemritkán a kutatás során elért sikeres magyarországi kínai vállalkozók szempontjából mindenképpen munkaidőnek minősülő időszakokban. Bár a kutatás az újonnan érkezettekre nem terjedt $\mathrm{ki}$, a kezdeti tájékozódás arra engedett következtetni, hogy a közelmúltban nem vállalkozási céllal Magyarországra érkezett „kulturbürger” kínai népesség gyerekgondozási modellje eltér a transznacionális vállalkozók kiszervezett gondoskodási formáitól.

Az 1990-es évek eleje óta a kínai vállalkozók magyarországi üzleti modellje átalakult; a ruhák és cipők helyi kiskereskedelmét felváltotta a kínai áruk sokkal szélesebb választékának nemzetközi nagykereskedelme. Számos kínai vállalkozás - akárcsak Dávidék családjáé is - hatalmasra nőtt, és gazdaságilag nagyon eredményes lett. A Magyarországon élő és nemzetközi kereskedelmi központokat kialakító kínaiak vállalkozásukat transznacionális alapon müködtették, miközben maguk is transznacionális életmódot folytattak, amely során az áruk és a személyek folyamatos mozgásban voltak Magyarország, Kína és az egyéb helyszínek között. A magyarországi kínai népesség munkájának világát célzó kutatásában Várhalmi Zoltán megerősítettnek találta Nyíri korábbi azon megállapítását, hogy a migráció segítette a női munkavállalást és a nők

${ }^{21}$ A kérdésről Nyíri Pál tartott előadást az MTA Kisebbségkutató Intézetében 2018. szeptember 20-án Új Kulturbürgerek. Kinai bevándorlók az illiberális Európában címmel.

REGIO 27. évf. (2019) 3. szám 149-182. 
vállalkozását is. ${ }^{22} \mathrm{Ha}$ arra teszünk kísérletet, hogy megértsük e transznacionális migráns népesség gyermekek gondozásával kapcsolatos gyakorlatait, szem előtt kell tartanunk a nők, köztük a női vállalkozók viszonylag magas arányát.

Bár a közelmúltig a nálunk élő kínaiak túlnyomó többsége vállalkozott, alacsonyabb arányban akadtak köztük olyan munkavállalók is, akik nem családtagként dolgoztak kínai cégeknél, vagy akik szabadúszó idegenvezetőként vagy tolmácsként tevékenykedtek. (A tágabb kutatás kínai közremúködői között a ténylegesnél magasabb arányban jelentek meg az e foglalkozási csoportokhoz tartozók, mert könnyebb volt kapcsolatba lépni velük. Azok közül a kínai szülők közül, akik alkalmazottként dolgoztak, senki nem szervezte ki a gyermekéről való gondoskodást a Dávidéhoz hasonló módon.)

Végül szeretném kiemelni, hogy a család fogalma miként jelent meg e kutatás kínai kontextusában. Várhalmi megállapította, hogy a család alapvető építőköve a transznacionális kínai vállalkozásoknak. ${ }^{23}$ Nagyon fontos hangsúlyozni ugyanakkor, hogy a család fogalma által előhívott asszociációk között a bizalom az első és a legfontosabb, és nem a családtagok közti intimitásalapú érzelmi közelség. ${ }^{24}$

Az egy gyermek politikájának 2015-ös eltörléséig a diaszpóralét egyben könnyebbé tette a kínai családoknak, hogy egynél több gyereket vállaljanak. E politika hatást gyakorolt a kínai vállalkozó szülök gyermekelhelyezési döntéseire is, amelyeket ugyancsak befolyásolt a gyermekek érkezési sorrendjében betöltött pozíció. A Kínában napvilágot látott elsőszülöttek akadálymentesen illeszkedtek a kínai adminisztráció rendszerébe, ezért jó esélyük volt, hogy visszaküldik őket Kínába, hogy rokonok gondoskodjanak róluk. A kínai szülők jelezték, hogy a helyzet minden további gyermek

\footnotetext{
22 Várhalmi Zoltán: A Távol-Keletről Magyarországra érkező állampolgárok munkavégzésének fő jellegzetességei, típusa. (Kutatási zárótanulmány) Budapest: MKIK Gazdasági és Vállalkozáselemző Intézet, 2009.

${ }^{23}$ Várhalmi, 2009.

${ }^{24}$ A kínai-magyar vegyesházasságokról készült kvalitatív kutatás megerősítette a család fogalmának szociokulturálisan meghatározott eltérő felfogásait. Ilyen különbségnek bizonyult a vegyes nukleáris családnak tulajdonított eltérő jelentőség a kínai és a magyar felek esetében. Több kínai fél a család kifejezés alatt saját kiterjedtebb kínai rokonságát értette. Ez az eltérő felfogás több pár esetében feloldhatatlan konfliktusokhoz vezetett. L. Kovács 2015. és 2016.
}

REGIO 27. évf. (2019) 3. szám 149-182. 
esetében összetettebb volt, és ez gyakran a gyerekek eltérő elhelyezési megoldásaihoz, eltérő bánásmódhoz vezetett az egy nukleáris családhoz tartozó gyermekek esetében is.

5. A kínai gyerekekről való gondoskodás formái Magyarországon - Tereptapasztalatok

A tanulmányban tett megállapítások elsősorban a gondoskodást végző magyar felnőttektől származó információkra támaszkodnak; ezt egészítik ki a pedagógusoktól, gyermekorvosoktól, esetileg a kínai családoktól származó adatok. Mint a módszertani részben jeleztem, beszélgetőpartnereim az 1990-es évek közepétől a terepmunka idejéig összesen 38 gyerekről gondoskodtak. Az egyes konkrét gyerekfelügyeleti megoldások mutattak bizonyos mértékü változatosságot a gyerekek életkora, a magyar gondozó felnőttel töltött idő tartama, a gondozás helyszíne és az egyéb szolgáltatások vonatkozásában. A kutatás egyik fő célja volt, hogy feltárja ezeket a gondoskodási megoldásokat, amelyek során a gyerekek magyar felnöttek otthonában, illetve több esetben rokonaiknál Kínában is töltöttek el időszakokat.

5.1. Kapcsolatfelvétel a kínai szülők és a gyerekekre vigyázó magyar felnöttek között

A kutatás látóterébe került esetekben a kapcsolatfelvétel két mintázat valamelyikét követte. Az első a gyermekellátás magyar állami intézményhálózatához kapcsolódott: az óvodai és bölcsődei alkalmazottak munkájuk során kerültek összeköttetésbe a kínai szülökkel. Miután kialakult egy sikeres szülö-gyerek-gondozó együttmüködés, ez továbbiak létrejöttéhez vezetett. A találkozásunkkor hatvanas évei közepén járó, nyugdíjazása előtt álló Jucika a három magyar óvónő beszélgetőtársam közül a kínai szülők körében talán a legnépszerübb gyerekfelügyeletet vállaló felnött volt, annak ellenére, hogy nem fogadott bentlakó gyereket. Jucika szigorú volt, a gondozói munkához egy saját szabályrendszert állított fel, amelynek betartását kínai gyerekektől és felnőttektől egyaránt elvárta. Lakásában nagyon hatékony korrepetáló órákat tartott az általános iskolai korosztálynak, valamint uzsonnával és igény szerint vacsorával is ellátta a tanítványait, illetve délutáni-esti szabadidős

REGIO 27. évf. (2019) 3. szám 149-182. 
felügyeletet is biztosított a számukra. Mindig több munkát kínáltak neki a kínai családok, mint amennyit el tudott vállalni; ezeket a lehetőségeket munkahelyi kollégáinak adta tovább.

A második mintázatban a kínai vállalkozók és a potenciális gyerekfelvigyázók közti spontán találkozásokat követően kialakult bizalom előzte meg a munkaajánlatot. Ilyen forgatókönyvet követett egy magyar felszolgáló és egy kínai vendég közti rendszeres találkozás egy nagy kínai bevásárlóközponttól nem messze eső kávézóban; egy főbérlői és egyben szomszédsági kapcsolat; és példa erre egy olyan magyar könyvelö unokahúga, aki éveken keresztül több kínai család vállalkozásának könyvelését végezte.

\subsection{A gyerekek életkora és a felügyelet időtartama}

A gyerekek különbözö életkorokban érkeztek a magyar felnőttek otthonába. A Magyarországon született gyerekek esetében jellemző kezdőpontot jelentett a pár hónapos életkor. A beszélgetőtársaim által említett legfiatalabb gyerekek 4-5 hetesen érkeztek, és közülük többen 2-3 éves korukig éltek magyar gondozójukkal. A néhány, rokonokkal töltött év után Kínából (vissza)érkező gyerekek az óvoda után, hatéves korukban vagy a kínai általános iskola néhány osztályának elvégzése után, tízéves korukban költöztek be magyar gondviselöjükhöz. Néhány Magyarországon született, de Kínában hosszabb időszakot eltöltött kisiskolás gyereket csak egy évre helyeztek el szülei ilyen módon, hogy egy magyar nyelvü háztartásban élve megtanuljon magyarul, és segítséget kapjon az iskolai feladataihoz. A legidősebb, egy évet bentlakóként töltő kínai gyerekek, akik a terepmunka látóterébe kerültek, 14 és 16 évesek voltak.

Főleg a Magyarországon született és folyamatosan itt élő gyerekek eseteiben beszélgetőtársaim több olyan szülői döntésről számoltak be, hogy az iskoláskort elért gyereket a szülök magukhoz vették, és akkortól a gyerek már csak a délutánjait, a kora estéket és a hétvégéit töltötte korábbi gondozójával, vagy egyes esetekben másik magyar személy otthonában, amíg szülei dolgoztak. Az említett 38 kínai gyerek többsége szülei otthonában aludt szombat esténként vagy minden második szombaton. A 6 évnél fiatalabb gyerekek jellemzően több hónapot töltöttek magyar gondozóik otthonában a nyári szünetben, amikor szüleik Kínába látogattak.

REGIO 27. évf. (2019) 3. szám 149-182. 
Magyar beszélgetőtársaim egyöntetüen arról számoltak be, hogy amikor először megállapodtak a szülökkel, nem tudták, milyen hosszú időszakra ígérkeznek el. Amikor a továbbiakban kérdezgették a szülöket, hogy elképzelésük szerint a gyermek pontosan mennyi ideig is él majd az otthonukban, a gyerekgondozói szolgáltatást vásárló szülők többnyire azt válaszolták, hogy még nem tudják pontosan, és az elöre várható időtartamot években becsülték meg. Négy interjúalanyom számolt be arról, hogy a szülők előzetes jelzés nélkül, egyik napról a másik mondták fel a megállapodást, és vitték el a gyermeket; ezeket a helyzeteket elmondásuk szerint érzelmi szempontból nehezen tudták kezelni. Mint kiderült, mind a négy esetben Kínában élő rokonokhoz küldték gondozásba a gyerekeket.

\subsection{A gondoskodás helyszínei}

A kutatás során megismert magyar gyermekfelvigyázók mindannyian saját otthonukban dolgoztak. Többségük folyamatosan bentlakó gyerekről is gondoskodott, emellett további gyerekek számára délutáni és hétvégi felügyeletet is vállalt. Két magas tandíjat számlázó, angol nyelvű magániskolában dolgozó pedagógus interjúalanyom két másik, jómódú kínai család gyerekeit érintő felügyeleti formáról is beszámolt. Találkoztak olyan tanulókkal, akik ugyan a kínai család otthonában éltek, azonban bentlakó magyar „nevelönőjük” volt, aki mindig a szolgálatukra állt és minden feladatukban segítette őket. Megint csak más kínai diákok ezekben az intézményekben állandó bébiszitterükkel egy külön bérelt lakásban laktak iskolájuk közelében. Az említett 38 fös kutatási mintából azonban 37 gyerek éveken keresztül a magyar gondozója lakásában lakott (bár ez nem jelentette azt, hogy önálló szobája lett volna ott).

\subsubsection{A gondoskodás helyszíne}

A gondozási munka terei és helyszíne központi szerepet töltenek be a migrációval összefüggésben létrejött gondoskodási formák szakirodalmában, és alapvető hatással vannak a gondozási szolgáltatást nyújtó és az azt megvásárló személyek között kialakuló

REGIO 27. évf. (2019) 3. szám 149-182. 
hatalmi viszonyokra25. A kiszervezett gondozási munka azon helyzeteiben, amelyek a harmadik világbeli gondozók globális migrációjának eredményként jöttek létre, a gondozási munka helyszíne jellemzően a szolgáltatást vásárló fél otthona. A jelen dolgozatban tárgyalt gondozási formában ezzel szemben a gondozási munka színtere a gondozási szolgáltatást nyújtó személy otthona volt. Öt beszélgetőtársam idézte fel igen élénken az első alkalmat, amikor a kínai apukák elöször léptek be az otthonukba. Az egyik apuka egy babaággyal érkezett; a gondozást elvállaló hölgy és a családtagjai tátott szájjal nézték, amint az fel-alá járkált az otthonukban, hogy az ágy számára legmegfelelőbb helyet megtalálja - a házaspár hálószobájában. A gondozó otthonában tett látogatások alkalmával több szülő szokásává vált, hogy bevonuljanak a konyhába, kinyissák a hütőszekrény ajtaját, és belekóstoljanak a lábasok, fazekak tartalmába. Személyes területük időszakos inváziója ellenére az a benyomásom alakult ki a terepmunka során, hogy a szolgáltatást vásárlók, azaz a jómódú kínai vállalkozók, és a szolgáltatók, azaz a közép- és alsó középosztálybeli magyar asszonyok közti hatalmi viszonyok kiegyensúlyozottabbak, és nagymértékben eltérnek azoktól a helyzetektől, ahol többnyire fehérbőrü, középosztálybeli, első világbeli nők vásárolnak gondozást gyenge anyagi helyzetü, harmadik világbeli migráns nőktől, és ahol a munkavégzés helyszíne jellemzően a vásárlók otthona. A cseh szociológusnő, Adéla Souralová hasonló hatalmi viszonyokat figyelt meg és írt le a Csehországban élő vietnami vállalkozók és a vietnami gyerekeket saját otthonukban gondozó cseh nőkröl. ${ }^{26}$

\subsection{Egyezkedés a szülők és a gyermekgondozók között}

Hasonlóságot mutattak azok a gondozói narratívák, amelyek azt beszélték el, milyen kezdeti lépéseken keresztül jutottak el a megegyezésig azokkal a kínai szülőkkel, akiknek a gyerekeire vigyáztak. Több esetben az utcán találkoztak elöször annak a kínai

\footnotetext{
${ }^{25}$ L. pl. Cheng, Shu-Ju. Ada: Contextual politics of difference in transnational care: The rhetoric of Filipina domestics' employers in Taiwan. Feminist Review 77. Labour Migrations: Women on the Move, 2004. 46-64.

${ }^{26}$ Souralová, Adela.: New perspectives of mutual dependency in care-giving. Farnham: Ashgate, 2015.
}

REGIO 27. évf. (2019) 3. szám 149-182. 
vagy magyar személynek a társaságában, aki összekötötte őket. Jellemzően nem találtak olyan közös nyelvet, amelyen mindannyian tudtak beszélni, ezért a kommunikáció akadozott, a részleteket nem sikerült tisztázni, és tág tere nyílt a félreértéseknek is, ennek ellenére megszületett valamiféle informális szóbeli megállapodás arról, hogy a gyereket a magyar gondozó otthonában helyezik el. Beszélgetőtársaim egybehangzó állítása szerint ezeket a tranzakciókat soha nem kísérték írásos szerződések vagy meghatalmazások. A magyarországi kínai munkavállalási formákról szóló írásában Várhalmi Zoltán tárgyalja azokat a munkával kapcsolatos helyzeteket, amelyekben írásos szerződések készülnek. ${ }^{27}$ Várhalmi rámutatott, hogy míg a magyar partnerekkel kötött üzleti megállapodásokat jellemzően írásos szerződésbe foglalják, ezek a dokumentumok teljességgel hiányoznak azokban az esetekben, amikor közeli vagy távolabbi kínai rokonokat alkalmaznak a kínai vállalkozások. Várhalmi nem tért ki a magyar munkavállalók alkalmazására ebben a vonatkozásban. A jelen tanulmányban említett informálisan létrejött gondozói munkamegbízásokhoz nem készültek írásos dokumentumok, e munkavégzés a feketegazdaságban zajlott.

A gyermekeket gondozó magyar felnőttek beszámolói szerint a szülök viszonylag nagy szabadságot hagytak nekik, hogy maguk döntsenek a gyerekekkel kapcsolatos mindennapi ügyekben. A szülök bizalmat hiteleztek az ismeretlen magyar személyeknek, és jellemzően a gyerek körüli tisztaságot, tápláló étkezéseket és szigorú nevelési attitüdöt vártak el tőlük. Elvárták azt is, hogy szükség esetén orvoshoz vigyék őket, és eljárjanak helyettük a szülöi értekezletekre. A magyar gondozók elmondása szerint alapvetően a kínai szülők határozták meg a szóbeli szerződés sarokpontjait.

\subsubsection{Megegyezés - konfliktusforrások}

Gyakran napokkal vagy hetekkel a megegyezést követően derült fény a közös mindennapokat érintő alapvető részletekkel kapcsolatos félreértésekre. Az egyik ilyen jellemző konfliktusforrás az akörüli bizonytalanság volt, hogy pontosan mikor és mennyi időt tölt a gyerek gondozója otthonában. Az első találkozáskor több szülő jelezte, nem tudja előre pontosan megmondani, melyik napon viszi el magával a

${ }^{27}$ Várhalmi, 2009.

REGIO 27. évf. (2019) 3. szám 149-182. 
gyereket és mennyi időre. A tíz év alatti gyerekekkel dolgozó gondozók egybehangzóan számoltak be arról a bizonytalanságról, hogy vajon az együtt töltött első hét után mikor bukkannak fel a gyerekért a szülei. A gyerekeket gondozó magyar személyek pihenőnapjának kérdése is rendszeres konfliktusforrást jelentett; többen felidézték, hogy voltak teljes hónapok, amikor pihenőnap nélkül vigyáztak a gondjaikra bízott gyerekekre a saját otthonukban. A betegségek megítélése és kezelése ugyancsak gyakran vezetett nézeteltérésekhez a szülők és a gondozók között. Ezek egyrészt az ideális kezelés meghatározása körül alakultak ki: több szülő elutasította például az antibiotikumok használatát, holott azt írta fel a gyerek számára a körzeti gyermekorvos. A gondozók közül többen tapasztalták, hogy a szülők nem tulajdonítanak jelentőséget a gyerek rossz egészségi állapotának, és sokan mesélték, hogy a szombati szülői látogatásról magas lázzal hozták vissza hozzájuk a gyerekeket.

Néhány beszélgetőpartnerem megjegyezte, hogy nagyon nehéz volt újratárgyalnia a kezdeti szóbeli megállapodás részleteit a kínai szülökkel. Ketten is említették, hogy plusz fizetséget próbáltak kialkudni a szülőktől azokra a napokra, amikor egy komolyabb betegség időszakában éjszaka is dolgozniuk kellett a náluk élö gyerekkel, csillapítaniuk kellett a lázát, be kellett vinniük az éjszakai ügyeletre. Ezek a próbálkozások jellemzően nem jártak sikerrel, mert a kínai szülők úgy érveltek, éjszaka nem kell dolgozni a gyerekkel.

\subsubsection{A szülői döntés kockázatai}

A kutatás során közvetett adatok gyültek olyan esetekről, amikor a szülők tévesen ítélték meg egy potenciális gondozó tulajdonságait, és úgy helyezték el a gyereküket, hogy az nyilvánvalóan nem volt jó a számára, és ezen a megoldáson később változtatniuk kellett. Kevin baba története jól példázza az ilyen eseteket. Ö egy kínai vállalkozó házaspár második gyerekeként született Budapesten 2013-ban, és beszélgetőpartnerem otthonába másfél évvel később érkezett meg. Kevin édesanyja és édesapja egy-egy üzletet vezettek, amelyek egy kiterjedtebb nagycsaládi vállalkozás részét képezték. Két különböző üzletközpontban dolgoztak minden nap, késő estig. Amint az eredetileg újszülött szakasszisztensi képzettségü interjúalanyom elmesélte, néhány héttel a születése után Kevint egy magyar asszony gondjaira bízták, akiknek a személyazonosságát Kevin szülei nem 
fedték fel előtte. Bár Kevin nem volt koraszülött, életének első 18 hónapjában sem testileg, sem szellemileg nem fejlödött kellő módon, és viselkedése arra utalt, hogy nem megfelelö ellátásban, bánásmódban részesült. Nem tudta jelezni a szükségleteit, lefejthetetlenül csimpaszkodott az őt felvevő felnőtt nyakába, vagy mozdulatlanul feküdt ott, ahova letették, és minden alkalommal nagyon megijedt, amikor hangos emberi beszédet hallott. Kevin szülei új helyet kerestek neki. Interjúalanyom, Kevin újabb gondozója családjában több gyerekegészségügyi szakember is volt, és a család Kevin problémáira komoly figyelmet összpontosított. Kevin két és fél éves volt, amikor a terepmunka során találkoztam vele; ekkor már kezdett felzárkózni a kortársaihoz. Több interjúalanyom hangsúlyozta, hogy sokkal nehezebb a helyzet azokban az esetekben, amikor a gyerek még túl fiatal ahhoz, hogy elmondja, mi történt vele.

\subsection{Díjazás}

A gyermekek kiszervezett gondoskodási formáinak díjazása, a szolgáltatási tételek árazása, a fizetés gyakorisága viszonylag nagy változatosságot mutatott, emellett a megkérdezettek közül nem mindenki beszélt fesztelenül és részletesen erről a témáról. A kutatás látóterébe került bentlakó gyerekek esetében a szülők javasolták az árat, és ők alakították ki a fizetés gyakoriságát. Bizonyos szülök heti időegységeket, más szülők napi időegységeket áraztak be, és általában a heti, kétheti fizetési gyakoriság volt a jellemző, de találkoztam olyan esetekkel is, ahol havi díjban állapodtak meg. Több szülő említette, hogy a szülök többsége az estét és az éjszakát nem tekintette a gondozó szempontjából munkavégzési időszaknak, és ezekre az időszakokra nem akartak fizetni. Ugyanakkor általánosan jellemző volt, hogy a szülők minden, a gyerekekkel kapcsolatban felmerülő kiadást álltak, ha azt szükségesnek ítélték meg.

A szolgáltatást nyújtók és a vásárlók körében is igyekeztem tájékozódni a díjak konkrét összegéröl, de gyakran nem kaptam kellően pontos választ. A szolgáltatást vásárlók és a szolgáltatást nyújtók válaszai között ellentmondás feszült: a vásárlók lényegesen magasabb havi összegeket említettek, mint a szolgáltatást nyújtó személyek. Ez kétséget ébresztett adataim helytállóságával kapcsolatban. Meg kell ugyanakkor jegyeznem, hogy az ellentmondónak tünő adatok nem ugyanabban a konkrét 
szolgáltatásban érintett felnőtt résztvevőktől származtak, és lehetséges, hogy jelentős árkülönbségek léteznek ezen a területen.

Álljon itt egy példa. Kevin baba gondozója a bentlakásos gondozásáért havi 110 ezer forintos havi díjazásban állapodott meg Kevin szüleivel. Nem tisztázták elöre, Kevin baba pontosan hány napot és éjszakát tölt majd gondozójánál egy hónap során, és ez végül több lett, mint amire a gondozó és családja számított, ugyanakkor nem sikerült Kevin szüleivel újratárgyalni és megemelni a havi összeget. A havi díj nem tartalmazta az étkezés költségeit, sem a Kevin babával kapcsolatos egyéb kiadásokat. Egy kínai anyuka viszont arról számolt be, hogy havonta 400 ezer forintot fizetett hasonló konstrukcióban kiszervezett hároméves kisfiának gondozásáért, bár ez az összeg a gyerek havi étkezését is magába foglalta. Viszonyítási pontot jelent, hogy Magyarországon 2015-ben 68.775 forint volt a nettó minimálbér. ${ }^{28}$ Itt érdemes felidézni azt is, hogy a Központi Statisztikai Hivatal számításai szerint a háztartások egy före jutó havi fogyasztási kiadásaiban az élelmiszerek és nem alkoholos italok átlagosan 19.885 forintot tettek ki 2015-ben. ${ }^{29}$

A gondozók tevékenysége két alapvető megélhetési modellt körvonalazott. Néhány interjúalanyomnak csak olyan gondozásból származó bevétele volt, amelyet a nála életvitelszerüen élő kínai gyerek után, heti hét napban, napi 24 órában a saját otthonában végzett munkáért kapott. Többségük napközbeni, délutáni és hétvégi felügyeletet és korrepetálást is nyújtott a kínai gyerekeknek, és jellemzően több gyerekkel dolgozott. Ök ezekért az időben pontosan körülhatárolt tevékenységekért egyértelmüen meghatározott összegeket kértek, és kevesebb munkaórából is lényegesen nagyobb bevételhez jutottak. A bentlakókat is fogadó magyar gondozók többen jelezték, délutánra és korrepetálásra is fogadnak (vagy szeretnének

\footnotetext{
${ }^{28}$ Forrás: https://officina.hu/gazdasag/93-minimalber-2015 Utolsó letöltés: 2019. november 30.

${ }^{29}$ Statisztikai tükör, 2016. április 8. A háztartások fogyasztása, 2015 (előzetes adatok alapján). Utolsó letöltés: 2019. november 30. Elérhető online: https://www.google.com/url?sa=t\&rct=j\&q=\&esrc=s\&source=web\&cd=1\&cad= rja\&uact=8\&ved=2ahUKEwj45Pes4ZbmAhUw_CoKHa6UDbQQFjAAegQIBB AJ\&url=https $\% 3 \mathrm{~A} \% 2 \mathrm{~F} \% 2 \mathrm{Fwww} . \mathrm{ksh} . \mathrm{hu} \% 2 \mathrm{Fdocs} \% 2 \mathrm{Fhun} \% 2 \mathrm{Fxftp} \% 2 \mathrm{Fstattukor}$ \%2Fhaztfogy\%2Fhaztfogy 1512.pdf\&usg=AOvVaw2QnNp1sDGRqDsZrcD31A1 1
}

REGIO 27. évf. (2019) 3. szám 149-182. 
fogadni) kínai gyerekeket, akik közül többen babaként vagy kisgyerekként korábban a háztartásukban éltek.

Mint arról esett már szó, a kutatás során megismert 14 gondozó a pályafutása során összesen 38 kínai gyereket nevelt egy-egy hosszabb időszakon keresztül a saját otthonában. Jóval magasabb a száma azoknak a gyerekeknek, akiket ugyancsak ők fogadtak hétköznap délutánonként és hétvégénként a kutatás időszakában. A kínai gyerekek mellett 6 és 11 év közötti vietnami és magyar fiúkkal és lányokkal is találkoztam a gondozók otthonaiban. Míg a magyar szülök alkalmanként fizettek, a vietnami szülök a kínaiakhoz hasonlóan nagyobb időegységekre megállapított átalánydíjat adtak.

A fizetséggel kapcsolatos elégedettségüket firtató kérdéseimre interjúalanyaim - föként az óvodáskorúnál fiatalabb gyerekről gondoskodó nők - közül hárman is magyar ismeröseiket idézték, aki szerint „nem normálisak”, hogy ennyi pénzért vállalják ezt a munkát, és beszéd közben azt metakommunikálták, hogy túlzottan alacsonynak tartják a fizetséget a folyamatos 24 órás szolgálatért. Ezt követően mindhárman megjegyezték, hogy pár hónap elteltével annyira megszerették a náluk élö kínai gyereket, hogy emiatt nem akarták elküldeni, annak ellenére, hogy a szülők nem voltak hajlandóak többet fizetni. Mint arról fentebb esett már szó, általános törekvés volt a kutatás látóterébe került gondozók körében, hogy ezt a problémát további gyerekekről való egyidejű gondoskodással orvosolják. Többen említették, hogy bár a fizetség nem túl magas, az otthonukban tudják végezni, és családtagjaik segítségének köszönhetően munkavégzésüket jellemzi egyfajta rugalmasság is.

\subsection{Az érzelmi kötődés és annak következményei}

A kiszervezett gondoskodás bentlakásos eseteiről szóló gondozói beszámolók gyakran utaltak arra, hogy nagyon erős ragaszkodás és kölcsönös érzelmi kapcsolat alakult ki a kínai gyerek és magyar gondozója között. A 2 és 6 év közötti gyerekek esetében ez szinte törvényszerüen bekövetkezö konfliktushoz vezetett, amikor szombat este a szülők megérkeztek a gondozó lakásába, hogy hazavigyék a gyereküket, és a gyerekek nem akartak velük hazamenni. Néha a szülők feladták a küzdelmet, és otthagyták a gyereket a gondozójánál, bizonyos esetekben pedig különleges átadás-átvételi forgatókönyvet

REGIO 27. évf. (2019) 3. szám 149-182. 
egyeztettek a gondozóval, hogy zökkenőmentesen oldják meg a gyerek számára érzelmileg nehéz helyzetet.

A kérdéskör szakirodalma központi problémaként tárgyalja a gondoskodás közben kialakult kötődést a gyerekhez, valamint ennek személyes árát és következményeit, gyakran a fehér börü, középosztálybeli szolgáltatást vevők, valamint a gondoskodást nyújtó, kiszolgáltatott helyzetben lévő migráns nők közti hatalmi egyenlőtlenség összefüggésében. Bár a tanulmányban tárgyalt esetekben a hatalmi viszonyok a helybéli szolgáltatók és a migráns vásárlók között az említetteknél kiegyensúlyozottabbnak tüntek, a magyar gondozók érdekérvényesítési képességét elbeszélésük szerint gyengítette, hogy érzelmileg involváltak lettek..$^{30}$

\section{A kinai gyerekeket nevelö magyar felnöttek}

Bár nagyon egyediek voltak interjúalanyaim személyes narratívái arról, hogy mikor, miért és hogyan kezdtek kínai gyerekekre vigyázni a saját háztartásukban, előtörténetük, személyes élethelyzetük és munkaerőpiaci pozíciójuk jellegzetes mintázatot mutatott. Különösen nehéz a helyzete annak a 45-65 közötti korosztálynak, amelybe interjúalanyaim is tartoztak, és akik viszonylag alacsony piaci értékü képzettségekkel rendelkeznek. Többségük elvált volt (14-böl 8 személy), semmiféle anyagi segítséget nem kapott elvált férjétöl, és ő volt a háztartás első számú kenyérkeresője. Öten közülük svájci frank alapú lakáshitelt vettek fel, és a megemelkedett törlesztőrészletek miatt vagy már eladták az otthonukat, vagy tervezték azt. Mindannyian komoly munkahelyi változás és új családi kihívások elött álltak, és éppen dönteniük kellett arról, milyen irányban folytassák tovább a pályájukat, amikor felmerült számukra a lehetőség, hogy kínai gyerekekre vigyázzanak.

Beszélgetőtársnőim közül három rendelkezett felsőfokú végzettséggel. Öten dolgoztak korábban is gyerekekkel, ketten óvónőként, egyikük óvodai dadusként, egy személy csecsemős nővérként és egy kerületi védőnőként. A két óvónő és az óvodai dadus munkatársak voltak egy budapesti óvodában, ahol a kutatás idején is

\footnotetext{
${ }^{30}$ Uttal, Lynet - Tuominen, Mary.:Tenuous relationships: Exploitation, emotion, and racial ethnic significance in paid child care work. Gender and Society, 13(6). 1999. 758-780.
}

REGIO 27. évf. (2019) 3. szám 149-182. 
alkalmazásban álltak. Mindhárman nem sokkal korábban váltak el, és elvált házastársuktól nem kaptak anyagi segítséget sem közösen felvett jelzáloghitelük törlesztéséhez, sem közös gyermekeik neveléséhez. A korábbi védőnő éppen felmondott az előző munkahelyén, amikor rábukkant egy kínai család álláshirdetésére, amelyben napi 24 órában kerestek szakképzett gyermekpedagógust egyéves kisfiuk mellé. Az ötödik asszony négy gyermeke születése elött bölcsődei pedagógusként dolgozott, és felnőtt gyerekei önállóvá válása után kezdett ebbe a munkába.

A kutatás közvetlen látóterébe került gyermekgondozók többsége munkanélküli volt, vagy a munkanélküliség határán állt, miután éveket töltöttek a munkaerőpiacon kívül saját gyermekeik felnevelésével. Egyetemi végzettség és egyéb magas munkaerőpiaci értékü szakképzettség híján nem láttak jó esélyt arra, hogy visszatérjenek a munka világába.

A kínai migráns gyerekek gondozásának itt tárgyalt megoldási formái jellegzetesen a női szolgáltatókhoz kapcsolódtak. A kutatás során elért gondozó személyek mindegyike nő volt, ő egyezett meg a szülökkel és ő vállalta el a gyermek felügyeletét. Hármukat segítette a munkában a házastársuk, négyüket pedig tinédzser vagy fiatal felnőtt gyermekeik. Mind a 14 beszélgetőtársam maga is szülő volt, mindannyian legalább két saját gyereket neveltek fel. Legfiatalabb interjúalanyom negyvenes évei közepén járt, a legidősebb a hatvanas éveiben, ám mindannyian évekkel a kutatás megkezdése elött váltottak erre a tevékenységre. Az egyik ötvenes éveiben járó házaspár az 1990-es évek elején fogadta otthonában az első kínai gyereket, és azóta folyamatosan élt náluk legalább egy, bizonyos időszakokban akár több gyerek is. Különleges tapasztalataik körvonalazták, miként alakulhat a kapcsolat a gyerekek és a rájuk vigyázó magyar felnőttek között hosszabb időtávon.

\section{A transznacionális vállalkozó családok}

Annak a 38 kínai gyereknek a szülei, akikről interjúalanyaim meséltek, egy alkalmazott pár kivételével mindannyian első generációs kínai migráns vállalkozók voltak; és közülük többen

REGIO 27. évf. (2019) 3. szám 149-182. 
Délkelet-Kínából érkeztek Magyarországra. ${ }^{31}$ Fontos hangsúlyozni, hogy ezekben a családokban az anyukák jellemzően önálló üzlettel rendelkeztek, vagy egymaguk feleltek a nagyobb családi cég egy-egy külön egységéért. Hétköznap és hétvégén egyaránt nagyon sokáig dolgoztak. Legjobb tudomásom szerint e vállalkozók többsége nem rendelkezett felsőfokú végzettséggel, és többnyire kisebb városokból vagy vidékről származtak. A gondozók úgy tudták, hogy a családok többsége saját ingatlanjában, többnyire üzleti érdekeltségei közelében lakott Budapesten. A kutatás látóterébe került gyerekeket, akik kisiskolás korban érkeztek vissza Kínából, a Kínai-Magyar Két Tanítási Nyelvü Általános Iskolába, vagy a gondozójuk lakhelye szerint illetékes körzeti iskolába íratták be.

A kiszervezett gondoskodás bentlakásos formája, valamint a délutáni felvigyázás és különórák költségét nyilvánvalóan nem minden kínai vállalkozó család engedhette meg magának. A második generációs kínai fiatalok identitását elemezve Beck olyan Magyarországon dolgozó kínai szülőkről számolt be, akik szívesebben választották volna gyermekeik számára a kiszervezett gondoskodás bentlakásos változatát Magyarországon, de ennek költségeit túl magasnak találták, ezért inkább Kínába küldték el a gyerekeket az ott élő nagyszülőkhöz. ${ }^{32}$

A kínai apák és anyák gyerekekkel kapcsolatos magatartása és nevelési gyakorlata számos területen ütközött a magyar gondozók szülöi magatartással kapcsolatos elvárásaival. Kivétel nélkül minden beszélgetőtársam felhívta a figyelmet arra, hogy a kínai szülők meglátásuk szerint merevebb gesztusokkal, visszafogottabb arcjátékkal, sokkal kevesebb testi kontaktussal kommunikáltak a gyerekeikkel. Többen úgy vélték, hogy az apák figyelmesebbek és érzelmesebbek a gyerekeikkel, mint az anyukák, akikről az a benyomásuk alakult ki, hogy az apukáknál kevésbé érdeklődnek a gyerekek iránt. Bár eltérően fogalmazták meg, minden bentlakó gyerekkel dolgozó interjúalanyom jelezte, hogy a gyerekek nagyon

${ }^{31}$ Ez a rész főleg a gondozóktól származó adatokra, és kisebb részben kínai fiataloktól származó észrevételekre épült. Bár találkoztam és röviden beszéltem néhánnyal az itt hivatkozott 38 kínai gyereke szülei közül, nem sikerült velük formális interjút készíteni. A 38 itt említett gyerektől független, e gondoskodási módot igénybe vevő szülőkkel készített interjúk anyaga nem szerepel ebben a tanulmányban.

${ }^{32}$ Beck, 2015.

REGIO 27. évf. (2019) 3. szám 149-182. 
erősen elkezdtek ragaszkodni hozzájuk, miközben kevéssé ragaszkodtak a szüleikhez, de ez a szülök számára láthatóan semmiféle problémát nem jelentett. Egyik interjúalanyom ezt így idézte fel: „El nem tudom képzelni, hogy hogy nem féltékenyek ránk, de nem azok, egyáltalán. Éppen ellenkezőleg, úgy tünik, örülnek neki, hogy a gyerekük ennyire szeret bennünket."

A gyerekeket gondozó magyar felnőtteknek és a kutatóknak egyaránt feltünt, hogy transznacionális vállalkozó családok gyakran eltérő bánásmódban részesítették a testvéreket. Az egy családon belül előforduló különböző forgatókönyvek semmiképpen nem az egyenlő bánásmód elvét jelenítették meg. A vállalkozó családok helyzete, anyagi erőforrásai, a vállalkozás aktuális állapota időről időre változhatnak a migráció folyamata során, és a posztmigrációs időszakban olykor kedvezőtlenül alakulnak. Így az induló vállalkozás előtt álló kihívások, vagy akár a korábban már említett egy gyermek politika hatása is hozzájárulhatott ahhoz, hogy magyarországi kínai gyerekeket - adataim közt gyakran az elsőszülötteket - évekre Kínába küldjenek a szüleik a nagyszülökhöz. A családban a sorban következő gyereket gyakrabban tartották Magyarországon, és a vállalkozás anyagi sikerességének függvényében mindennapi gondozását a jelen tanulmányban tárgyalt bentlakásos formában szervezték ki.

A testvérek egyenlőtlen bánásmódjánál is érdekesebb kérdés azonban, hogy a transznacionális vállalkozó szülök miért ezt a gondozási formát választják. A magyarországi kínai népesség nem vállalkozó tagjaival, valamint a Nyugat-Európában élő magasan kvalifikált kínai bevándorlókkal e gyermekgondozási módról beszélgetve megerősítést nyert az, hogy a kínai szülők többsége számára fontos, hogy napi szinten saját maga személyesen gondoskodjon a gyermekéröl. A szakirodalom is alátámasztja, hogy a kínai társadalom modernizációja és individualizációja, ${ }^{33}$ a gyerekszülő kapcsolatok tartalmának változásai, ${ }^{34}$ a érzelmek és a szerelem növekvő elfogadottsága a házasság kritériumaként ${ }^{35}$ mind olyan fejlemények, amelyek hatással lehetnek a gyerekneveléssel kapcsolatos normákra és gyakorlatokra. A kutatás látóterébe került

\footnotetext{
${ }^{33}$ Yan, 2009.

${ }^{34}$ Evans, 2010; Fong, 2002.

${ }^{35}$ Efron Pimentel, Ellen: Just how do I love Thee?: Marital relations in urban China. Journal of Marriage and Family, 62(1). 2000. 32-47.
}

REGIO 27. évf. (2019) 3. szám 149-182. 
szülők többségét kitevő nem túl magasan iskolázott, vidéki vagy kisvárosi népesség valószínüleg a kínai társadalom családi értékek és szokások terén kevésbé modernizálódott szegmenséhez tartozik.

A kínai vállalkozó szülők kiszervezett gyermekgondozása szorosan összefügg szülői stratégiáik jellegzetességeivel. Egy kultúraközi összehasonlító pszichológiai vizsgálat szerzői kínai és indiai óvodás gyerekek anyukáinak szocializációs céljait és szülői gyakorlatait vetették össze. Két pekingi és két, az indiai bengalurui városi óvodához kapcsolódó, felső középosztálybeli, többségében felsőfokú végzettséggel rendelkező anyukák közt felvett adatok alapján azt találták, hogy a szülők iránti engedelmességgel, a szocioemocionális fejlődéssel és az autoritatív szülői magatartással összefüggő kapcsolati minták eltérnek a kínai és az indiai anyák esetében. A kutatók kérdésfelvetése szorosan kapcsolódik a Diane Baumrind által felállított szülői kontroll-tipológiához, konkrétan az autoriter és az attól nagymértékben különböző autoritatív szülöi gyakorlathoz. $^{36}$ Baumrind szülöi kontroll tipológiája alapján a pszichológiai irodalom megkülönbözteti az autoritatív és az autoriter szülő magatartást. Az autoritatív szülők magas elvárásokat támasztanak, ám reszponzívak, megértőek, megbocsátóak és érzelmesek a gyerekeikkel, emellett támogatják a gyermekek döntéseit és önálló érvelését. Az autoriter szülők elvárásai szintén magasak, ám ők nem reszponzívak a gyerekeikkel, nem ismerik el azok érzelmi szükségleteit, viszont élnek a testi fenyítés eszközével, valamint elvárják gyermekeiktől, hogy magyarázat nélkül is kövessék az utasításaikat. „Az autoriter szülők elsődleges feladatuknak tekintik, hogy gyerekeik akarata meghajoljon az autoritás előtt". ${ }^{37}$

Rao és szerzőtársainak eredményei szerint a kínai anyák úgy vélték, hogy a szocio-emocionális fejlődést célzó autoritatív

\footnotetext{
${ }^{36}$ Baumrind, Diana: Effects of Authoritative Parental Control on Child Behavior. Child Development, 37(4), 1966. 887-907.

${ }^{37}$ Darling, Nancy: Thinking About Kids. Authoritative vs. Authoritarian Parenting Style. Forrás: https://www.psychologytoday.com/blog/thinking-aboutkids/201409/authoritative-vs-authoritarian-parenting-style 2014.

Utolsó letöltés: 2018. július 1.
}

REGIO 27. évf. (2019) 3. szám 149-182. 
magatartás akadályozza a szülők iránti engedelmesség megvalósulását, valamint a magas iskolai teljesítmény elérését. ${ }^{38}$

Az autoriter szülői magatartásnak (amely az autoritatív magatartás ellentéte) számos eleme volt megfigyelhető a kutatás látóterébe került kínai szülők viselkedésében, például a gyerekek érzelmi igényeinek látszólagos figyelmen kívül hagyása, a gyerekek iránti érzelmek elrejtése, valamint a testi fenyítés szükség szerinti alkalmazásának bátorítása a gyerekeket gondozó magyar felnőtteknél.

\section{8. Összefoglalás}

A tanulmányban tárgyalt antropológiai kutatás a Magyarországon dolgozó kínai migráns vállalkozó szülők kiszervezett gyermekgondozási formáira, valamint a kínai családok és a magyar gondozók között kialakult viszonylatokra irányult. Ez a dolgozat a jelenségegyüttes antropológiai bemutatására törekedett, elsősorban a gondozási munkát végző magyar személyek nézőpontjából.

A terepmunka és a szakirodalom egyaránt megerősítik, hogy a kiszervezett gyermekgondozás bentlakásos formájának megjelenése az 1990-es évek elejére, a magyarországi kínai diaszpóra létrejöttének időszakára tehető. A kínai családi kapcsolatok szakirodalma és a magyarországi transznacionális vállalkozói körön kívül álló kínai migránsokkal folytatott informális kommunikáció egyaránt abba az irányba mutattak, hogy a kínai szülők jellemzően napi szinten is saját maguk igyekeznek ellátni a gyermekeiket. A terepkutatás egyértelműen körvonalazta a magyar gondozók csoportjának (gyenge munkaerőpiaci helyzetü, középkorú, középosztálybeli nők), valamint azoknak a kínai családoknak (transznacionális migráns vállalkozók, köztük vállalkozó anyukák, családi alapú vállalkozásokkal) a társadalmi, kulturális és gazdasági jellemzőit, akik ezt a fajta kiszervezett magyarországi gyermekgondoskodási formát kombinálták a kínai nagyszülők Kínában éveken át nyújtott gondoskodásával.

A kutatás során elért magyar gondozók gyenge munkaerőpiaci helyzetü, közép- és alsó középosztálybeli, középkorú magyar nök

\footnotetext{
${ }^{38}$ Rao, Nirmala - McHale, James - Pearson, Emma: Links between socialization goals and child-rearing practices in Chinese and Indian mothers. Infant and Child Development, 2003. 12(5). 475-492.
}

REGIO 27. évf. (2019) 3. szám 149-182. 
voltak. A tárgyalt gyerekgondoskodási forma kialakulásában a posztszocialista Magyarország gazdasági viszonyai és társadalmi kontextusa is szerepet játszottak. A transznacionális kelet-ázsiai vállalkozói migrációhoz kapcsolható jelenség párhuzamai a szakirodalom alapján alapvetően Közép-Kelet-Európa néhány volt szocialista országában jöttek létre. ${ }^{39}$ A kiszervezett gondoskodás e formáiban résztvevő szülők meghatározóan migráns vállalkozók és nem alkalmazottak voltak. A kínai nők migrációja, köztük a női vállalkozók magas aránya a magyarországi kínai népességen belül, valamint a vállalkozásokban rejlö gyors növekedési lehetőség olyan tényezők, amelyek fontosak e jelenségek létrejöttének megértésében.

A kutatás adatai a transznacionális kínai vállalkozásokat vizsgáló kutatások eredményeivel egybehangzóan jelzik a család meghatározó szerepét, tükrözik ugyanakkor eltérő értelmezését a kínai diaszpóra kontextusában. A kínai szülők gyerekekkel való bánásmódja és a gondozóknak a gyerekekre vonatkozóan adott ajánlásai a szigor és a testi fenyítés alkalmazásáról a nem reszponzív, autoriter szülői attitüd ismérvei. A szakirodalom arra is utalt, hogy anyagi okok miatt kevesebb család engedhette meg magának ezt a gondoskodási megoldást, mint szerette volna.

A magyar felnőttek otthonában élve a kínai gyerekek nemcsak a magyar nyelvet tanulták meg, hanem olyan kulturális kódrendszert sajátítottak el, amely kívül sárga, belül fehér „banán” identitásuk kialakulásához is hozzájárult. A gondozóik otthonában töltött hosszabb időszakok alatt megtapasztalt nevelési stratégia vagy gondoskodás több olyan elemet tartalmazott, amely az autoriter stratégiával ellentétes autoritatív szülői magatartásra volt jellemző. Ez utóbbi támogatta a gyerekek szocio-emocionális fejlődését és jellemzően bensőséges érzelmi kapcsolat kialakulásához vezetett a róluk gondoskodó magyar felnőttekkel.

A bizalom, az informalitás és a bizonytalanság a kínai családok és a magyar gondozók közti viszony több területét jellemezték. Ez a globális munkamigrációval összefüggésben létrejött gondoskodási forma jóval kiegyensúlyozottabb hatalmi viszonyokat mutatott a gondoskodást nyújtók és a gondoskodást vásárlók között, mint azokban az esetekben, amikor harmadik világbeli migráns nök nyújtják ezeket első világbeli, fehérbőrü, jómódú nőknek, utóbbiak

${ }^{39}$ L. Souralová, 2015.

REGIO 27. évf. (2019) 3. szám 149-182. 
otthonában. A kínai vállalkozók anyagi helyzete és fogyasztási képessége felülmúlta a gondozói csoport tagjaiét, ugyanakkor társadalmi helyzetükre kedvezötlen hatással voltak a befogadó társadalom negatív elöítéletei az ázsiai bevándorlókkal szemben. A gondozói munkavégzés tere - a gondozó otthona - saját országában helyezkedett el, és saját ellenőrzése alatt állt. Minden bentlakó gyerek gondozója számára pozitív élményt jelentett a kínai gyerekekkel kialakult bensőséges érzelmi kapcsolat. Végül, a szülök és gondozók közti hatalmi viszonyok dinamikáját ugyancsak befolyásolták a gondozók gondoskodásról és anyaságról vallott, ugyancsak kulturálisan kondicionált elképzelései, amelyek alapján erkölcsi szempontból a kínai vállalkozó anyák felett állónak érezték magukat, mert azok másra bíztak a kisgyerekeikről való gondoskodást.

A gyerekekről való kiszervezett gondoskodás e dolgozatban tárgyalt megoldásai, amely során a magyar gondozó otthonában töltött időszakokat időnként a nagyszülőkkel töltött többéves szakaszok egészítettek ki Kínában, a transznacionális életformától elválaszthatatlan, annak részeként létrejött szülői gyakorlatok. Elválaszthatatlanok a magyarországi kínai transznacionális vállalkozó szülök körében megfigyelt autoriter szülöi magatartástól. Szorosan összefüggenek a családdal kapcsolatos szociokulturálisan kondicionált elképzelésekkel, normákkal és értékekkel, amelyek nem elsősorban a családtagok és az egymást követő generációk közti bensőséges, érzelmi kötelék létrejöttét célozzák. Ugyancsak szorosan kapcsolódnak a kínai migráns vállalkozók családi alapú transznacionális üzleti modelljéhez is. A gyerekek földrajzi, térbeli mobilitását az a kilátás indokolja és teszi elfogadhatóvá, hogy az az egész családi csoport hosszabb távú javát, gazdasági növekedését és társadalmi mobilitását szolgálja majd; bár nyilvánvalóan nem közvetlenül a gyerekek egyéni sikerességét vagy boldogságát célozza. A kutatás idején 11 éves Dávid szülei egy ,jobb holnap" 40 reményében, és a kiterjedt családi csoport hosszú távú céljai és ambíciói által vezérelve szervezték ki a gyermekeikről való gondoskodást.

Dávid és a hozzá hasonló kínai-magyar gondoskodási konstrukcióban nevelkedett gyerekek helyzete nemcsak a magyarországi, hanem a kínai integráció problémaköréhez is

${ }^{40}$ Souralová, 2015. 60.

REGIO 27. évf. (2019) 3. szám 149-182. 
kapcsolódik. A gyerekek magyar gondozókkal kialakult kapcsolata, a gondoskodás intenzív, autoritatív formái konfliktusokhoz vezethetnek ugyanazon kínai migráns vállalkozó család első és a második generációi között. Dávid történetét és tapasztalatait nem lehet megérteni, ha nem vesszük figyelembe a családja által a gyorsan változó kínai családi kapcsolatok kontextusában alkalmazott szülői stratégiát, valamint a gazdaságilag vezérelt transznacionális migráció folyamatát. Dávid és kortárs honfitársainak posztmigrációs tapasztalatai megkérdőjelezhetetlenül egyedi és különleges epizódjai az utóbbi évtizedek Közép-Kelet-Európa felé irányuló kínai transznacionális családi mobilitásának.

\section{Felhasznált irodalom}

Baumrind, Diana: Effects of Authoritative Parental Control on Child Behavior. Child Development, 37(4). 1966. 887-907.

Beck Fanni: De ha a tükörbe nézek, az arcom kínai. Másodgenerációs kínai fiatalok hibrid identitáskonstrukciói. Budapest: MAKAT Antroport, 2015.

Chen, F. - Liu, G. - Mair, C.: Intergenerational ties in context: Grandparents caring for grandchildren in China. Social Forces, 90(2). 2011. 571-594. DOI: 10.1093/sf/sor012

Cheng, Shu-Ju Ada.: Contextual politics of difference in transnational care: The rhetoric of Filipina domestics' employers in Taiwan. Feminist Review 77, Labour Migrations: Women on the Move, 2004. 46-64.

Darling, Nancy: Thinking About Kids. Authoritative vs. Authoritarian Parenting Style. Forrás:

https://www.psychologytoday.com/blog/thinking-aboutkids/201409/authoritative-vs-authoritarian-parenting-style 2014.

Efron Pimentel, Ellen: Just how do I love Thee?: Marital relations in urban China. Journal of Marriage and Family, 62(1) 2000. 32-47. 
Evans, Harriet: The gender of communication: changing expectations of mothers and daughters in urban China. The China Quarterly, 204. Gender in Flux: Agency and Its Limits in Contemporary China. December 2010. 980-1000.

Fong, Vanessa. L.: China's one-child policy and the empowerment of urban daughters. American Anthropologist, 2002. 104(4). 10981109.

Fresnoza-Flot, Asuncion - Nagasaka, Itaru (eds.): Mobile childhoods in Filipino transnational families. New York: Palgrave Macmillan, 2015.

Koncz Katalin: A nők munkaeröpiaci helyzete az ezredfordulón Magyarországon. Statisztikai Szemle, 82. 2004/12. 1092-1107.

Korac Sanderson, Maja: Chinese traders in Serbia: Gender opportunities, translocal family strategies and transnational mobility. Ars\&Humanities, special issue Many Faces of Migration, VII(2). 2013. 86-98. DOI: 10.4312/ah.7.2.

Kovács, Nóra: Cultures unfolding: Experiences of Chinese-Hungarian mixed couples in Hungary. Current Issues in Personality Psychology, 2015. 3(4). 254-264. DOI: 10.5114/cipp.2015.54328.

Kovács, Nóra: Global migration and intermarriage in ChineseHungarian context. In: Ducu, Viorela - Telegdi-Csetri, Áron (eds.): Managing difference in Eastern-European transnational families . Frankfurt: Peter Lang, 2016. 113-131.

Kwok-bun, Chan (szerk.): International Handbook of Chinese Families. New York: Springer, 2013.

Makay Zsuzsanna: Családtámogatás, gyermeknevelés, munkavállalás. In: Monostori Judit - Öri Péter - Spéder Zsolt (szerk.): Demográfiai portré. Budapest: KSH, 2015. 57-75.

Naftali, Orna: Empowering the child: Children's rights, citizenship and the state in contemporary China. The China Journal, 2009. 61. 79-103. DOI: $10.2307 / 20648046$

REGIO 27. évf. (2019) 3. szám 149-182. 
Nyíri Pál: Kínaiak és afgánok Magyarországon: két migráns csoport érvényesülési stratégiái. In: Feischmidt Margit - Nyíri Pál (szerk.), Nem kívánt gyerekek? Külföldi Gyerekek magyar iskolákban ). Budapest: MTA Nemzeti-Etnikai Kisebbségkutató Intézet Nemzetközi Migrációs és Menekültügyi Kutatóközpont, 2006. 39-74.

Nyíri Pál: Kínai migránsok Magyarországon: Mai tudásunk és aktuális kérdéseink. In: Hárs Ágnes - Tóth Judit (szerk.): Változó migráció - változó környezet. Budapest: MTA PTI, 2010. 147-171.

Parreñas, Rhacel Salazar: Transnational Mothering: A Source of Gender Conflicts in the Family. University of North Carolina Law Review, 2010. 88(5). 1825-1856. DOI: 10.1007/978-3-53194127-1_9

Paveszka Dóra - Nyíri Pál: Oktatási stratégiák és a migráns tanulók iskolai integrációja. In: Feischmidt Margit - Nyíri Pál (szerk.): Nem kivánt gyerekek? Külföldi Gyerekek magyar iskolákban ). Budapest: MTA Nemzeti-Etnikai Kisebbségkutató Intézet Nemzetközi Migrációs és Menekültügyi Kutatóközpont, 2006.129-169.

Rao, Nirmala - McHale, James - Pearson, Emma: Links between socialization goals and child-rearing practices in Chinese and Indian mothers. Infant and Child Development, 2003, 12(5). 475492.

Souralová, Adela.: New perspectives of mutual dependency in caregiving. Farnham: Ashgate, 2015.

Stafford, Charles (szerk.) Ordinary ethics in China, LSE Monographs on Social Anthropology 79. London: Bloomsbury, 2013.

Statisztikai tükör, 2016. április 8. A háztartások fogyasztása, 2015. (elözetes adatok alapján) 
Uttal, Lynet - Tuominen, Mary:Tenuous relationships: Exploitation, emotion, and racial ethnic significance in paid child care work. Gender and Society, 13(6). 1999. 758-780.

Várhalmi, Zoltán: A Távol-Keletről Magyarországra érkező állampolgárok munkavégzésének fö jellegzetességei, típusa. Budapest: (Kutatási zárótanulmány) MKIK Gazdasági és Vállalkozáselemző Intézet, 2009.

Wang, Leslie. K.: Outsourced Children. Orphanage Care and International Adoption in Globalizing China. Stanford University Press, 2016.

Yan, Yunxiang.: The individualization of Chinese society, LSE Monographs on Social Anthropology 77. Oxford: Berg Publishers, 2009.

REGIO 27. évf. (2019) 3. szám 149-182. 